\title{
Transgenic mice expressing a truncated form of CREB-binding protein (CBP) exhibit deficits in hippocampal synaptic plasticity and memory storage
}

\author{
Marcelo A. Wood, ${ }^{1,4}$ Michael P. Kaplan, ${ }^{1}$ Alice Park, ${ }^{1,2}$ Edward J. Blanchard, ${ }^{1}$ \\ Ana M.M. Oliveira, ${ }^{1}$ Thomas L. Lombardi, ${ }^{1,3}$ and Ted Abel ${ }^{1,4}$ \\ ${ }^{1}$ Department of Biology, University of Pennsylvania, Philadelphia, Pennsylvania 19104, USA
}

\begin{abstract}
Deletions, translocations, or point mutations in the CREB-binding protein (CBP) gene have been associated with Rubinstein-Taybi Syndrome; a human developmental disorder characterized by retarded growth and reduced mental function. To examine the role of CBP in memory, transgenic mice were generated in which the CaMKIll $\alpha$ promoter drives expression of an inhibitory truncated CBP protein in forebrain neurons. Examination of hippocampal long-term potentiation (LTP), a form of synaptic plasticity thought to underlie memory storage, revealed significantly reduced late-phase LTP induced by dopamine-regulated potentiation in hippocampal slices from CBP transgenic mice. However, four-train induced late-phase LTP is normal. Behaviorally, CBP transgenic mice exhibited memory deficits in spatial learning in the Morris water maze and deficits in long-term memory for contextual fear conditioning, two hippocampus-dependent tasks. Together, these results demonstrate that CBP is involved in specific forms of hippocampal synaptic plasticity and hippocampus-dependent long-term memory formation.
\end{abstract}

Studies have demonstrated a pivotal role for transcription in learning and memory, from early experiments showing that RNA synthesis inhibitors block long-term memory without altering short-term memory, to studies in Drosophila, Aplysia, and mice demonstrating that transcription factor cAMP response element binding protein (CREB) is involved in long-term memory (Lonze and Ginty 2002; Kaplan and Abel 2003). Use-dependent changes in synaptic strength in the hippocampus and other brain regions are thought to underlie memory storage. One intensely studied form of synaptic plasticity is hippocampal long-term potentiation (LTP), a persistent, activity-dependent form of synaptic enhancement (Bliss and Richter-Levin 1993; Martin and Morris 2002). CREB has been shown to be involved in certain types of hippocampal LTP as well as long-term memory (for review, see Kaplan and Abel 2003). In most cases, CREB activates transcription of target genes by recruiting the coactivator CREB-binding protein (CBP) (Goodman and Smolik 2000), via the interaction between the Ser-133 phosphorylated kinase-inducible domain (KID) of CREB and the KIX domain of CBP (Chrivia et al. 1993). CBP stimulates transcription in two ways: via its intrinsic histone acetyltransferase (HAT) activity and via recruitment of components of the general transcriptional machinery (for review, see Vo and Goodman 2001).

A role for CBP in memory storage was first demonstrated in a mouse model of Rubinstein-Taybi Syndrome (Oike et al. 1999). RTS is a human developmental disorder characterized by retarded growth and reduced mental function (Rubinstein and Taybi 1963; Hennekam et al. 1992; Cantani and Gagliesi 1998), caused by breakpoints, microdeletions and point mutations in CBP (Petrij et al. 1995; Coupry et al. 2004). Mice heterozygous for an

Present addresses: ${ }^{2}$ Department of Cell Biology, Georgetown University Medical Center, Washington, DC 20057, USA; ${ }^{3}$ Keck School of Medicine, University of Southern California, Los Angeles 90033, CA, USA. ${ }^{4}$ Corresponding authors.

E-mail marcelow@sas.upenn.edu; fax (215) 898-8780.

E-mail abele@sas.upenn.edu; fax (215) 898-8780.

Article and publication are at http://www.learnmem.org/cgi/doi/10.1101/ Im.86605. inhibitory truncated CBP allele, lacking the HAT domain and carboxyl terminus, showed many features of RTS such as growth retardation, cardiac anomalies, and skeletal abnormalities as well as deficient long-term memory (Oike et al. 1999; Bourtchouladze et al. 2003). These results suggest that CBP may have a role in long-term memory, but this interpretation needs to be made with caution due to the significant developmental abnormalities in this mouse model of RTS in which the alterations in CBP are not spatially or temporally restricted.

To examine the role of CBP in memory independent of its role in development or in peripheral tissues, we generated transgenic mice that express CBP $\Delta 1$, an inhibitory truncated CBP protein lacking the HAT domain and carboxyl terminus. CBP 1 is expressed from the calcium/calmodulin-dependent protein kinase II $\alpha(\mathrm{CaMKII} \alpha)$ promoter, which drives expression postnatally in neurons within the hippocampus, striatum, amygdala, and cortex (Mayford et al. 1996; Kojima et al. 1997). CaMKII $\alpha$-CBP $\Delta 1$ transgenic mice exhibit deficits in specific forms of hippocampal synaptic plasticity and impairments in spatial learning and long-term memory for contextual fear conditioning. Our analysis of CaMKII $\alpha-\mathrm{CBP} \Delta 1$ transgenic mice suggests that this transcriptional coactivator has a role in synaptic plasticity and memory storage.

\section{Results}

\section{Generation of transgenic mice expressing truncated CBP (CBP $\Delta 1)$}

$\mathrm{CBP} \triangle 1$ is based on the CBP truncation mutant generated by Oike et al. (1999) in their screen to identify genes associated with development in mice. Heterozygous CBP-deficient mice, which express the truncated CBP protein (lacking amino acids 10842441) thought to be acting as a dominant negative inhibitor, showed clinical features of Rubinstein-Taybi syndrome (RTS) (Oike et al. 1999). We deleted amino acids 1084-2441 to generate the same inhibitory form of CBP (CBP $\Delta 1)$. CBP $\Delta 1$ contains the CREB-binding domain (KIX), which interacts with CREB and 
other factors, but lacks the BROMO domain and the histone acetyltransferase (HAT) domain in the carboxy-terminal half of CBP (Fig. 1A). Importantly, the CBP $\Delta 1$ truncation mutant is predicted to bind factors that interact with the amino terminus of CBP. Thus only a subset of CBP-interacting factors, including CREB, should be affected by this mutant.

CBP $\Delta 1$ was FLAG-epitope tagged (Wood et al. 2000) and expressed from the CaMKII $\alpha$ promoter (Mayford et al. 1996) to restrict transgene expression spatially to forebrain neurons. A transgenic approach was chosen because it allowed for expression of the CBP truncation product to be spatially restricted to neurons within the hippocampus, striatum, amygdala, and cortex as well as temporally restricted to post-natal development (Kojima et al. 1997) in order to avoid the developmental effects and lethality observed in more conventional CBP mutations (Tanaka et al. 1997; Oike et al. 1999). Additionally, CBP is thought to be present in the cell at limiting concentrations (for review, see Kamei et al. 1996; Vo and Goodman 2001) and due to transgene copy number and transgene insertion effects, different transgenic lines may have different levels of expression resulting in a range of impairments in CBP function. Three independent transgenic mouse lines expressing FLAG-CBP $\Delta 1$ were generated. The three lines had low (line 1352), medium (line 1353), and high (line 1364) levels of transgene expression as determined by semiquantitative in situ hybridization. Even though there is a wide range of expression from line 1352 to line 1364, all three lines have 25-30 transgene copies, as determined by Southern blot analysis (data not shown). As shown in Figure 1B, the transgene is expressed in the hippocampus, amygdala, striatum, and cortex in line 1364 . All three lines were analyzed behaviorally, but as

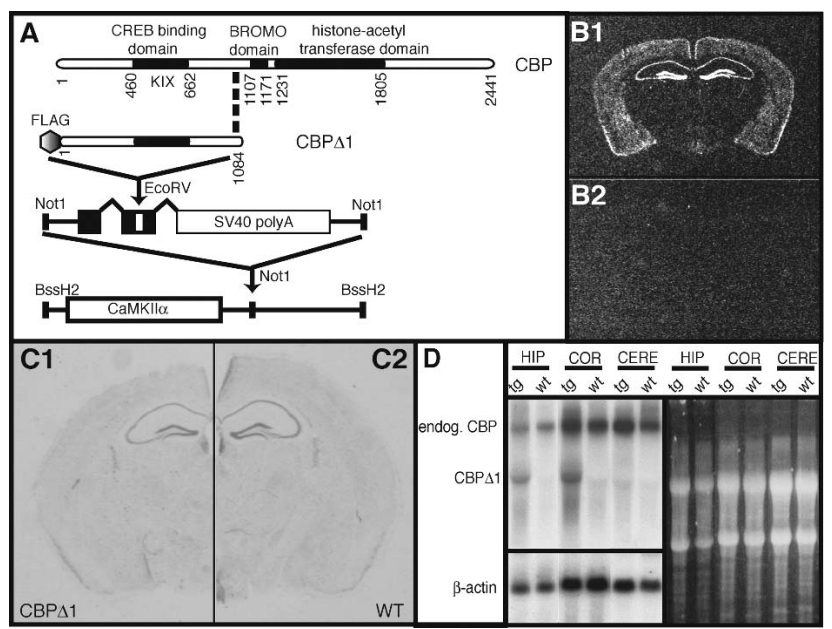

Figure 1. Generation of CaMKIl $\alpha-C B P \Delta 1$ transgenic animals. $(A) \mathrm{A}$ mouse CBP CDNA truncation mutant, including amino acids 1-1084, was FLAG-epitope tagged at the amino terminus and cloned into a vector containing intron and exon sequences with splice sites and the SV40 polyadenylation signal. This entire sequence was then cloned downstream of the $8.5 \mathrm{~kb}$ mouse CaMKIl $\alpha$ promoter. This construct was then used to generate CaMKIl $\alpha-C B P \Delta 1$ transgenic mice via pronuclear injection. (B) Coronal sections from the brains of $C B P \Delta 1$ transgenic mice (B1) and a wild-type littermate (B2) were hybridized with a probe specific to the CBP $\triangle 1$ transgene. Expression of the transgene is observed in the hippocampus, cortex, striatum, and amygdala. (C) Coronal sections from a CBP $\Delta 1$ transgenic mouse (C1) and a wild-type littermate (C2) were Nissl stained to confirm integrity of the hippocampus and other structures. $(D)$ Total RNA was isolated from the hippocampus, cortex, and cerebellum of CaMKIl $\alpha$-CBP 1 transgenic mice and wild-type littermates and analyzed by Northern blot. The membrane was first hybridized to an aminoterminal CBP radiolabeled probe, stripped, and then subject to a $\beta$-actin radiolabeled probe. The ethidium bromide-stained RNA gel is also shown, revealing $18 \mathrm{~S}$ and $28 \mathrm{~S}$ rRNAs. only line 1364 exhibited hippocampus-dependent memory deficits, we focused on line 1364 for further analysis.

The CaMKII $\alpha$ promoter does not become active until 10-21 d post-partum (Kojima et al. 1997) and expression is restricted spatially to forebrain neurons, which may be one reason why CBP $\Delta 1$ transgenic mice do not have the developmental impairments (growth retardation, significantly reduced weight, retarded osseous maturation and other skeletal abnormalities, cardiac abnormalities, and seizures) observed in the heterozygous CBP-deficient mice generated by Oike et al. (1999). CBP $\Delta 1$ transgenic mice are developmentally similar to their wild-type littermates. There was no observable weight difference between $\mathrm{CBP} \Delta 1$ transgenic males $(27.8 \pm 1.2 \mathrm{~g})$ and wild-type male littermates $(25.4 \pm 1.3 \mathrm{~g})(t[7]=1.11, p=\mathrm{NS})$ or between CBP 1 transgenic females $(21.3 \pm 0.4 \mathrm{~g})$ and wild-type female littermates $(20.8 \pm 0.4 \mathrm{~g})(t[7]=0.83, p=\mathrm{NS})$. To observe locomotor activity and anxiety, mice were examined on the elevated zero maze. No differences were observed in the number of transitions between the open and closed quadrants $(t[22]=1.21, p=\mathrm{NS})$, head pokes into open quadrants $(t[22]=0.19, p=N S)$, or time spent in the open quadrant $(t[22]=1.47, p=$ NS). In Figure $1 \mathrm{C}$, Nissl staining of coronal sections from CBP $\Delta 1$ transgenic (C1) and wild-type littermates (C2) showed no gross morphological differences. Northern blot analysis showed that the CBP $\Delta 1$ transcript is expressed in the hippocampus and cortex, but not the cerebellum, of CBP $\Delta 1$ transgenic mice (Fig. 1D). Quantification of the CBP $\Delta 1$ transcript and endogenous CBP transcript revealed that the transgene product is expressed at $95 \%$ of endogenous CBP levels in the hippocampus and $84 \%$ of endogenous CBP levels in the cortex. We used Affymetrix U74Av2 microarrays to examine changes in gene expression at basal conditions. Five $\mathrm{CBP} \Delta 1$ transgenic mice and five wild-type littermates were taken from their homecages, hippocampi were dissected, and cRNA target was prepared according to the recommended protocol (Affymetrix). Data were processed using Robust Multiarray Average (RMA) (Bolstad et al. 2003). Statistical Analysis of Microarray (SAM) (Tusher et al. 2001) was used to estimate the significance of expression changes between transgenic and wild-type animals. In these basal-state conditions, we did not observe any significant changes in hippocampal gene expression between CBP $\Delta 1$ transgenic mice and wild-type littermates, including no differences in the following housekeeping genes: tubulin, $\beta$-actin, $28 \mathrm{~S}$ $r R N A$, ribosomal proteins RPL23 and RPL13A, hprt, gapdh, and $u b c$ (M.A. Wood, M.B. Keeley, C. Isiegas, K. Hellman, J. Stein, and T. Abel, unpubl.).

The truncated CBP mutant in CBP $\Delta 1$ transgenic mice was designed to interrupt transcription factors utilizing CBP as a coactivator for the expression of their target genes. One such transcription factor is CREB. To examine the effect of the truncated CBP mutant on CRE-mediated transcription, we expressed it in HEK293 cells along with a CRE-luciferase reporter gene. CREmediated transcription induced by forskolin/IBMX treatment was inhibited by CBP $\Delta 1$ by $\sim 75 \%$ (Fig. 2 ). Normalized CRE-luciferase levels reached $53.1 \pm 6.8$ relative light units (RLUs), but only $11.9 \pm 0.9$ RLUs in the presence of the truncated CBP mutant, indicating that this CBP mutant significantly affects CRE-dependent forskolin-stimulated transcription $(t[10]=6.01, p<0.0001)$.

\section{Reduced long-term potentiation in the hippocampus of CBP $\Delta 1$ transgenic mice}

Long-term potentiation (LTP), the activity-dependent change in the strength of neuronal connections, is a form of long-lasting synaptic plasticity that has been proposed as a cellular mechanism of learning and memory (for review, see Martin and Morris 2002). To determine whether CBP 1 transgenic mice exhibit

\section{Learning \& Memory \\ www.learnmem.org}




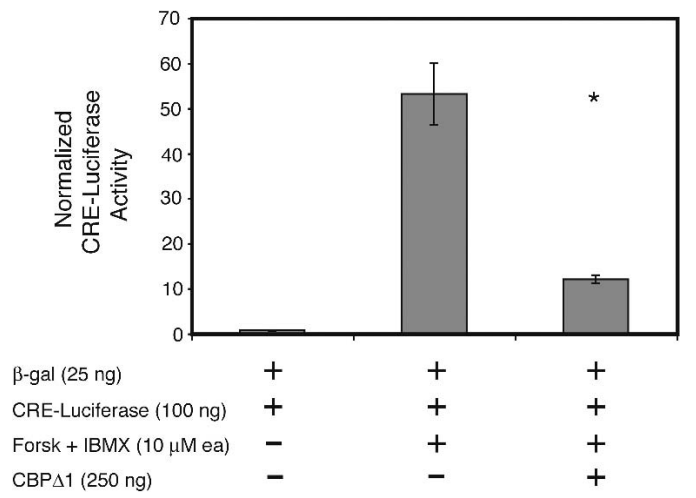

Figure 2. $C B P \triangle 1$ inhibits $C R E-m e d i a t e d$ transcription in tissue culture. The truncated CBP mutant (CBP $\Delta 1)$ inhibits CRE-mediated transcription by $\sim 75 \%$. Normalized CRE-luciferase levels reached $53.1 \pm 6.8$ relative light units (RLUs), but only $11.9 \pm 0.9$ RLUs in the presence of the truncated CBP mutant, showing that this CBP mutant affects CRE-dependent transcription. * indicates $p<0.0001$.

deficits in LTP, we characterized three forms of LTP in the CA1 region of hippocampal slices from mutant mice and their wildtype littermates: the transient early form of LTP resulting from a single $1 \mathrm{sec}, 100 \mathrm{~Hz}$ train (E-LTP), and the longer-lasting forms of LTP resulting from four $1 \mathrm{sec}, 100 \mathrm{~Hz}$ trains delivered $5 \mathrm{~min}$ apart (tetraburst L-LTP), or from a single $100 \mathrm{~Hz}$ train delivered in the presence of a D1 dopaminergic agonist, chloro-APB hydrobromide (Pittenger et al. 2002). The enhancement of LTP by D1 agonists is reduced by K-CREB, a dominant negative form of CREB (Pittenger et al. 2002), suggesting that it might also be affected by the inhibitory CBP $\Delta 1$ mutant. Conversely, E-LTP and tetraburst L-LTP are not affected by K-CREB and are predicted to be unaffected by the inhibitory CBP 1 mutant.

Before examining changes in LTP, it was necessary to determine whether hippocampal slices from CBP $\Delta 1$ transgenic mice showed any significant changes in baseline synaptic transmission. Field potentials in the CA1 region were elicited with bipolar stimulating electrodes placed in the Schaffer collaterals and characterized with respect to initial slope, peak amplitude, and inputoutput relationship. Hippocampal slices from CBP $\Delta 1$ transgenic and wild-type littermates were similar with respect to these baseline parameters (Fig. 3). Field potentials in slices from wild type and CBP $\Delta 1$ transgenic mice exhibit similar waveforms (Fig. 3A,B, respectively), and a scatter plot relating the initial slope of the fEPSP to the size of the presynaptic fiber volley (Fig. 3C) shows that expression of CBP $\Delta 1$ in transgenic animals $(n=7$ slices from four mice) does not change the input-output characteristics in area CA1 as compared to wild-type littermates $(n=4$ slices from three mice). There was also no difference in maximum responses, with average initial slopes of $-4.8 \pm 0.3$ for wild type and $-4.6 \pm 0.3 \mathrm{mV} / \mathrm{msec}$ for transgenic littermates (Fig. 3D; $t[19]=0.26, p=\mathrm{NS} ; n=26$ slices from 16 wild-type mice and $n=32$ slices from 15 CBP $\Delta 1$ transgenic mice).

To determine whether short-term forms of synaptic plasticity are affected by expression of CBP $\Delta 1$ in transgenic mice, we examined post-tetanic potentiation and paired pulse facilitation, a form of short-term synaptic plasticity that is sensitive to changes in presynaptic probability of release (Zucker 1989), in hippocampal slices from CBP $\Delta 1$ transgenic and wild-type littermates. When pairs of stimuli were delivered at interstimulus intervals from 25 to $300 \mathrm{msec}$, both wild type ( $n=15$ slices from eight mice) and CBP $\Delta 1$ transgenic hippocampal slices $(n=21$ slices from nine mice) display similar levels of facilitation (Fig. $3 \mathrm{E}-\mathrm{G})$. There were also no significant differences in post-tetanic potentiation following a single $1 \mathrm{sec}, 100 \mathrm{~Hz}$ train, either in control saline (Fig. $3 \mathrm{H} ; t[14]=0.78, p=\mathrm{NS} ; n=10$ slices from eight wild-type mice and $n=11$ slices from eight CBP 1 transgenic mice), or in the presence of chloro-APB (Fig. $4 \mathrm{~B} ; t[10]=0.33$, $p=\mathrm{NS} ; n=5$ slices from five wild-type mice and $n=7$ slices from seven CBP $\Delta 1$ transgenic mice).

To assess the effects of the expression of CBP $\Delta 1$ on longterm potentiation, test pulses were delivered once per minute to the Schaffer collaterals and the resulting fEPSPs were recorded. After recording stable baseline fEPSP responses for at least 15 min, LTP was induced by one of three protocols. When tetraburst L-LTP was induced by four $1 \mathrm{sec}, 100 \mathrm{~Hz}$ trains delivered $5 \mathrm{~min}$ apart, average responses for hippocampal slices from wild-type mice ( $n=6$ slices from five mice) and CBP $\Delta 1$ transgenic mice ( $n=7$ slices from four mice) show that this form of LTP is not significantly different between groups (Fig. $4 \mathrm{~A} ; F_{[1,1099]}=0.24$, $p=\mathrm{NS}$ ), with average potentiation at $60 \mathrm{~min}$ at $165 \pm 5 \%$ of control for wild-type mice and $161 \pm 11 \%$ for CBP $\Delta 1$ transgenic mice (Fig. 4B). To study a second form of LTP, sections were treated with $10 \mu \mathrm{M}$ chloro-APB in $0.05 \% \mathrm{EtOH}$ for $25 \mathrm{~min}$, followed by a single $1 \mathrm{sec}, 100 \mathrm{~Hz}$ train. Average responses for hippocampal slices from wild-type mice ( $n=5$ slices from five mice) and CBP $\Delta 1$ transgenic mice ( $n=7$ slices from seven mice) show that this form of LTP is significantly reduced in CBP $\Delta 1$ transgenic mice (Fig. $4 C ; F_{[1,1150]}=9.41, p<0.05$ ), with average potentiation at $60 \mathrm{~min}$ at $216 \pm 13 \%$ of control for wild-type mice and $176 \pm 8 \%$ for $\mathrm{CBP} \Delta 1$ transgenic mice (Fig. $4 \mathrm{D} ; t[10]=2.68$, $p<0.05)$. In contrast, there was no difference between hippocampal slices from wild-type mice ( $n=4$ slices from three mice) and CBP $\Delta 1$ transgenic mice ( $n=5$ slices from four mice) in the E-LTP resulting from a single $1 \mathrm{sec}, 100 \mathrm{~Hz}$ train in control saline (Fig. $4 \mathrm{E} ; F_{[1,426]}=0.23, p=\mathrm{NS}$ ), with no differences between wild type $(133 \pm 5 \%$ of control) and CBP $\Delta 1$ transgenic mice (135 $\pm 9 \%$ of control) in the average potentiation at $60 \mathrm{~min}$ (Fig. $4 \mathrm{~F} ; t[6]=0.50, p=\mathrm{NS}$ ). These results indicate a role for CBP in long-lasting hippocampal synaptic plasticity induced by pairing tetanic electrical stimulation and D1 receptor activation.

\section{$\mathrm{CBP} \Delta 1$ transgenic mice exhibit deficit in spatial learning as observed in the hidden-platform version of the Morris water maze}

The hidden-platform version of the Morris water maze, a hippocampus-dependent task, requires an animal to learn and remember the relationships between multiple distal cues and the platform location to escape the water (for review, see Lipp and Wolfer 1998; D'Hooge and De Deyn 2001). Acquisition of this task normally requires between six and 10 days of training depending on the genetic background of the mouse and the number of trials per day (Kogan et al. 1997; Lipp and Wolfer 1998). As shown in Figure $5 \mathrm{~A}, \mathrm{CBP} \Delta 1$ transgenic mice have a significant overall impairment in acquisition as compared to wild-type littermates (main effect of genotype: $F_{[1,133]}=7.07, p<0.05$; main effect of day: $F_{[7,133]}=6.89, p<0.0001$; genotype $\mathrm{X}$ day interaction: $\left.F_{[7,133]}=0.82, p=\mathrm{NS}\right)$. CBP $\Delta 1$ transgenic mice $(35.0 \pm 5.2 \mathrm{sec})$ reached an acquisition plateau on the fifth day of training whereas wild-type littermates $(21.1 \pm 4.3 \mathrm{sec})$ reached a significantly lower average escape latency. There was no difference in swim speed (main effect of genotype: $F_{[1,133]}=1.87, p=\mathrm{NS}$ ) or percent time spent floating (defined as swimming less than $5 \mathrm{~cm} / \mathrm{sec}$ ) between the two groups (main effect of genotype: $\left.F_{[1,133]}=0.24, p=\mathrm{NS}\right)$. CBP $\Delta 1$ transgenic mice did demonstrate significantly more thigmotaxis (swimming in the outer $10 \%$ of the pool) during training than did wild-type littermates (main effect of genotype: $\left.F_{[1,133]}=5.92, p<0.05\right)$. To assess spatial 
A

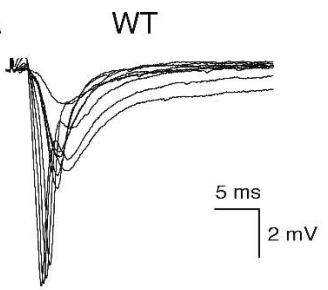

B

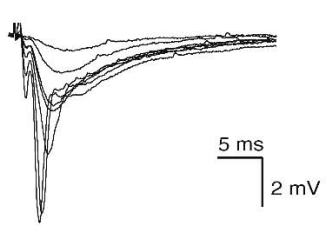

$E$

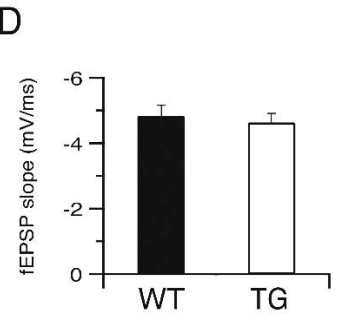

G

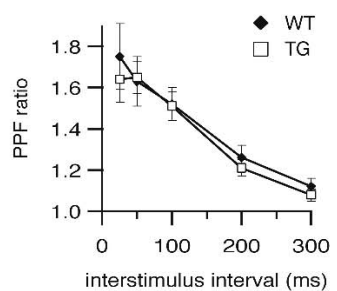

$\mathrm{H}$

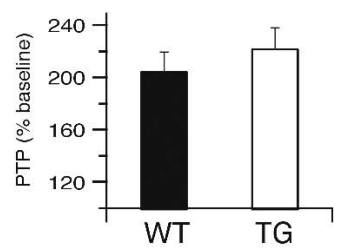

C

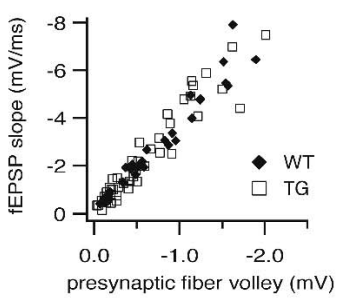

F

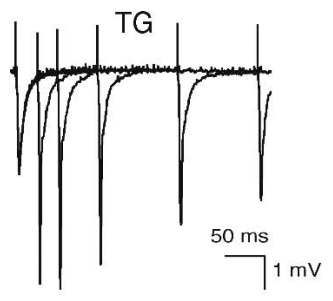

Figure 3. Baseline electrophysiological properties are normal in CBP $\Delta 1$ transgenic mice. $(A-C)$ Inputoutput characteristics were examined by recording field potentials (fEPSPs) in area CA1 resulting from stimuli of increasing intensity delivered to the Schaeffer collaterals in $400 \mu \mathrm{m}$ hippocampal slices from wild type $(A)$ and CBP 1 transgenic mice $(B)$. Plots of fEPSP initial slopes versus the corresponding presynaptic fiber volley amplitudes $(C)$ are similar in slices from wild-type littermates $(n=4$ slices from three mice) and CBP 1 transgenic mice ( $n=7$ slices from four mice). (D) Maximum fEPSP slopes are similar in CBP 1 transgenic mice ( $n=32$ slices from 15 mice) and wild-type littermates $(n=26$ slices from 16 mice). Sample traces of paired pulse facilitation at 25, 50, 100, 200, and $300 \mathrm{msec}$ are shown in slices from wild type $(E)$ and CBP $\Delta 1$ transgenic mice $(F)$. (G) Paired-pulse facilitation is not significantly different between wild type ( $n=15$ slices from eight mice) and CBP $\Delta 1$ transgenic mice $(n=21$ slices from nine mice) at interstimulus intervals between 25 and $300 \mathrm{msec}$. $(H)$ Post-tetanic potentiation is not altered in CBP $\Delta 1$ transgenic mice ( $n=11$ slices from eight transgenic mice and $n=10$ slices from eight wild-type mice).

memory more directly, the mice were subject to probe trials, in which the platform was removed and the mice were allowed $60 \mathrm{sec}$ to search the pool. The search pattern of an animal reveals spatial bias, which is thought to represent spatial long-term memory (Schenk and Morris 1985). There were no significant differences observed between groups on the probe trial the day after the fourth session (data not shown; main effect of quadrant: $F_{[3,57]}=1.94, p=\mathrm{NS}$; main effect of genotype: $F_{[1,57]}=2.35$, $p=\mathrm{NS}$; genotype $\mathrm{X}$ quadrant interaction: $F_{[3,57]}=0.62, p=\mathrm{NS}$ ). However, during the probe trial at the end of training on the tenth day, CBP $\Delta 1$ transgenic mice spent significantly less time in the target quadrant, where the platform was located during training, than wild-type littermates (Fig. 5B; main effect of quadrant: $F_{[3,57]}=3.78, p<0.05$; main effect of genotype: $F_{[1,57]}=0.97$, $p=$ NS; genotype X quadrant interaction: $F_{[3,57]}=3.36, p<0.05$ ). Wild-type mice show a preference for the target quadrant relative to other quadrants whereas CBP $\Delta 1$ transgenic mice do not show a spatial preference (Fig. 5B). No differences were observed in swim speed, floating, or thigmotaxis between the two groups during the probe trial (swim speed: $t[19]=0.89, p=$ NS; floating: $t[19]=0.48, p=N S$; thigmotaxis: $t[19]=1.67, p=N S$ ). We have also observed significant impairments in a recently derived $C B P \Delta 1$ transgenic mouse line (line 1611) for the hidden platform version of the water maze (data not shown), supporting our findings in the CBP 1 transgenic mouse line 1364 presented here.

There was no difference observed between $\mathrm{CBP} \Delta 1$ transgenic mice and wild-type littermates in escape latencies during training in the visible platform version of the water maze (Fig. 5C; main effect of genotype: $F_{[1,33]}=0.58$, $p=$ NS). Both groups did improve across days demonstrating that the task was acquired (main effect of day: $F_{[3,33]}=13.45$, $p<0.0001$; genotype $\mathrm{X}$ day interaction: $\left.F_{[3,33]}=0.53, p=\mathrm{NS}\right)$. A different set of mice were used for the visible platform version of the water maze than for the hidden platform version. Overall, these results indicate that $\mathrm{CBP} \Delta 1$ transgenic mice have impaired spatial learning.

\section{CBP $\Delta 1$ transgenic mice exhibit impaired contextual fear conditioning but normal cued fear conditioning}

Contextual and cued fear conditioning are two forms of associative learning that induce effective memory for either the context or the cue after a single training session (e.g., Abel et al. 1997; LeDoux 2000). These two types of fear conditioning are thought to require partially distinct, but overlapping, neural systems. Lesions of the hippocampus affect contextual conditioning whereas lesions of the amygdala affect both contextual and cued conditioning (for review, see Maren 2001). Memory for the conditioned stimulus was measured as freezing, an absence of visible movement, when presented with the conditioned context or cue in a $24 \mathrm{~h}$ retention test. CBP $\Delta 1$ transgenic mice and wild-type littermates showed the same level of freezing before and after the shock on training day (Fig. 6A; preshock: wild-type mice exhibited $0.2 \pm 0.2 \%$ freezing; transgenic mice exhibited $0.4 \pm 0.2 \%$ freezing; $t[36]=0.52, p=\mathrm{NS}$; post-shock: wild-type mice exhibited $8.3 \pm 2.5 \%$ freezing; transgenic mice exhibited $12.1 \pm 2.9 \%$ freezing; $t[36]=0.95, p=\mathrm{NS}$ ). However, when re-exposed to the conditioned context $24 \mathrm{~h}$ later, CBP $\Delta 1$ transgenic mice show a significant decrease in freezing compared to their wild-type littermates (Fig. 6A; $24 \mathrm{~h}$ test: wild-type mice exhibited $57.6 \pm 3.4 \%$ freezing; transgenic mice exhibited $44.9 \pm 4.1 \%$ freezing; $t[36]=2.37, p<0.05$ ). To assess whether $\mathrm{CBP} \Delta 1$ transgenic mice have normal short-term memory for contextual fear, a separate set of CBP $\Delta 1$ transgenic mice and wildtype littermates were tested in the conditioned context $1 \mathrm{~h}$ after training (Fig. 6B). CBP $\Delta 1$ transgenic mice and wild-type littermates showed similar levels of freezing $1 \mathrm{~h}$ after training (Fig. 6B; wild-type mice exhibited $45.0 \pm 5.2 \%$ freezing; transgenic mice exhibited $41.9 \pm 5.3 \%$ freezing; $t[20]=0.69, p=$ NS). This indicates that CBP 1 transgenic mice have normal short-term memory for the conditioned context.

\section{Learning \& Memory}

www.learnmem.org 
A

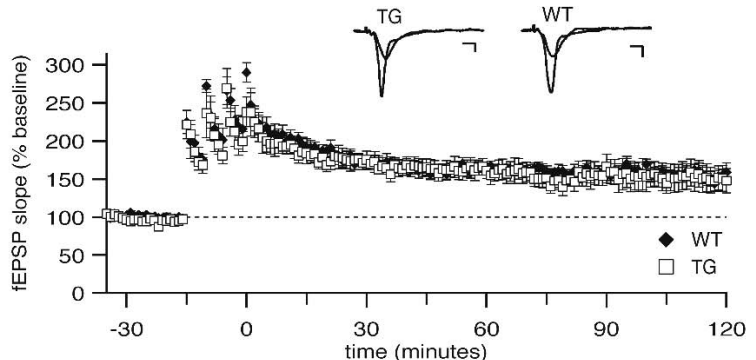

C

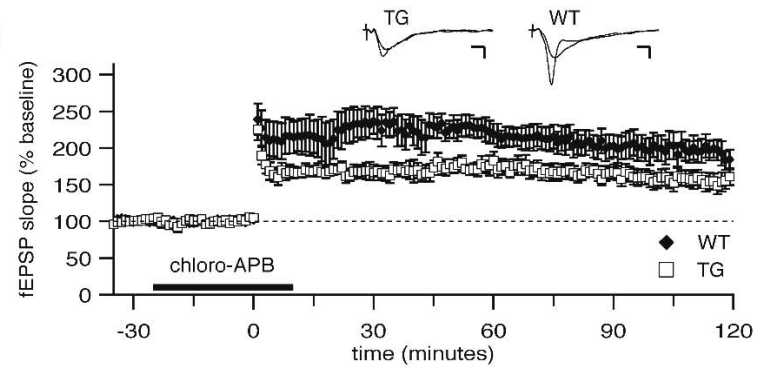

$\mathrm{E}$

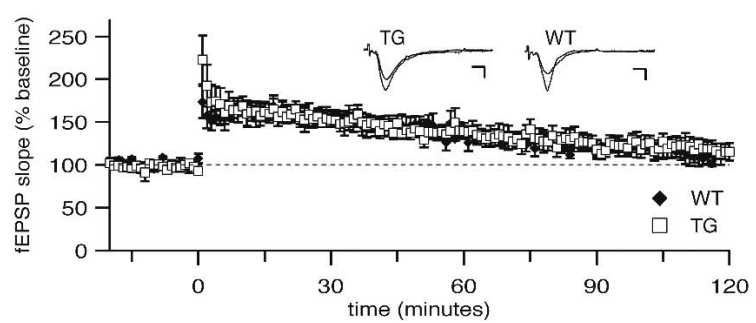

Figure 4. Long-term potentiation deficits in CBP 11 transgenic mice. $(A)$ Long-term potentiation (LTP) at Schaffer collateral synapses in response to four $1 \mathrm{sec}, 100 \mathrm{~Hz}$ trains administered 5 min apart is normal in CBP $\Delta 1$ transgenic mice. Both CBP $\Delta 1$ transgenic mice ( $n=7$ slices from four mice) and wild-type littermates ( $n=6$ slices from five mice) show stable potentiation. Insets show superimposed sample sweeps from before and $60 \mathrm{~min}$ after tetanic stimulation for CBP $\Delta 1$ transgenic mice and wild-type littermates. (B) At 60 min following tetanic stimulation, wild-type mice showed potentiation to $165 \pm 5 \%$ of control, and CBP $\Delta 1$ transgenic mice showed potentiation to $161 \pm 11 \%$ of control. (C) LTP in response to a single $1 \mathrm{sec}, 100 \mathrm{~Hz}$ train in the presence of a D1 dopaminergic agonist (10 $\mu \mathrm{M}$ chloro-APB hydrobromide) is impaired in CBP $\Delta 1$ transgenic mice. Both CBP 1 transgenic mice ( $n=7$ slices from seven mice) and wild-type littermates ( $n=5$ slices from five mice) show stable potentiation, but CBP $\Delta 1$ transgenic hippocampal slices show significantly reduced LTP. (D) At 60 min following tetanic stimulation, wild-type mice showed potentiation to $216 \pm 13 \%$ of control, whereas CBP $\Delta 1$ transgenic mice showed significantly decreased potentiation to $176 \pm 8 \%$ of control. $(E)$ Long-term potentiation in response to a single $1 \mathrm{sec}, 100 \mathrm{~Hz}$ train in control saline is not significantly different between slices from CBP 1 transgenic mice $(n=5$ slices from four mice) and wild-type littermates ( $n=4$ slices from three mice). (F) At 60 min following tetanic stimulation by a single $1 \mathrm{sec}$ $100 \mathrm{~Hz}$ train in control saline, wild-type mice $(133 \pm 5 \%$ of control) show equivalent potentiation to CBP $\Delta 1$ transgenic mice $(135 \pm 9 \%$ of control). * indicates $p<0.05$. Scale bars: $3 \mathrm{msec}, 1 \mathrm{mV}$.

A different set of CBP $\Delta 1$ transgenic and wild-type mice that were naive to fear conditioning were used for the cued fear conditioning experiment. CBP $\Delta 1$ transgenic mice and wild-type littermates showed the same level of freezing before and after the shock on training day (Fig. 6C; preshock: wild-type mice exhibited $1.1 \pm 0.6 \%$ freezing; transgenic mice exhibited $1.4 \pm 0.9 \%$ freezing; $t[20]=0.31, p=\mathrm{NS}$; post-shock: wild-type mice exhibited $13.1 \pm 4.7 \%$ freezing; transgenic mice exhibited $6.3 \pm 3.1 \%$ freezing; $t[20]=1.03, p=\mathrm{NS}$ ). No differences were observed in the $24 \mathrm{~h}$ retention test, performed in a novel context, between groups either before or after the cue (Fig. 6C; pre-CS: wild-type mice exhibited $16.5 \pm 2.9 \%$ freezing; transgenic mice exhibited $17.5 \pm 2.6 \%$ freezing; $t[20]=0.26, p=\mathrm{NS}$; CS: wild-type mice exhibited $77.6 \pm 3.8 \%$ freezing; transgenic mice exhibited $78.9 \pm 4.1 \%$ freezing; $t[20]=0.23, p=\mathrm{NS}$ ).
$\mathrm{B}$
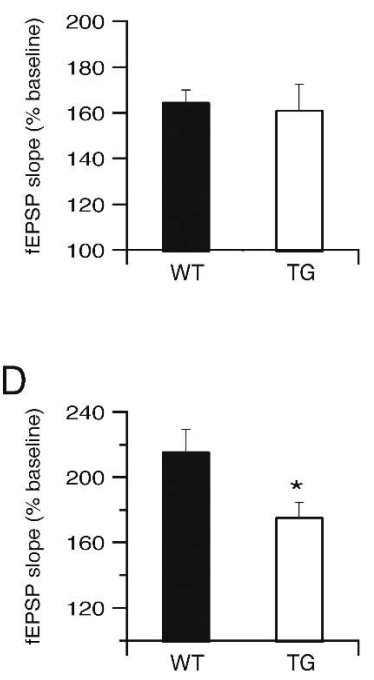

$\mathrm{F}$

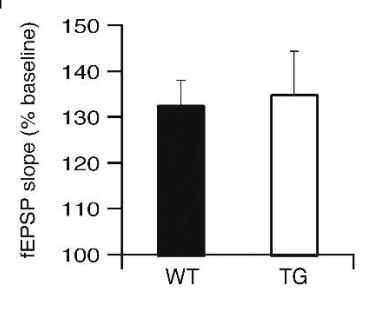

\section{Discussion}

We have shown that CBP is involved in a specific form of hippocampal synaptic plasticity and spatial and contextual hippocampus-dependent memory. In $\mathrm{CBP} \Delta 1$ transgenic mice, we observed a reduction in LTP induced by a single tetanus paired with a D1 dopaminergic agonist, the first demonstration of a role for CBP in this form of LTP. Behaviorally, we found that CBP $\Delta 1$ transgenic mice have spatial memory deficits in the hidden-platform version of the Morris water maze, which were not due to visual, motivational, or motor coordination difficulties. Additionally, long-term memory for contextual fear conditioning was impaired in $C B P \Delta 1$ transgenic mice, supporting the idea that CBP may have a specific role in hippocampusdependent learning and memory.

\section{Role for CBP in}

\section{hippocampus-dependent memory}

We generated $\mathrm{CBP} \Delta 1$ transgenic mice that express an inhibitory truncated CBP mutant because this mutant CBP protein appears to act in a dominant negative fashion (Oike et al. 1999). Indeed, we found CBP $\Delta 1$ to significantly impair CRE-dependent transcription. The $\mathrm{CBP} \Delta 1$ truncation mutant is predicted to bind only to factors that interact with the amino terminus of this transcriptional coactivator. Factors that bind to $\mathrm{CBP} \Delta 1$ do not recruit HAT activity because of the removal of this domain in $\mathrm{CBP} \Delta 1$. Thus, only a subset of CBPinteracting factors, including CREB, should be affected by this mutant. This same inhibitory truncated CBP mutant is expressed by mice generated by Oike et al. (1999), which have one wild-type CBP allele and one truncated CBP allele, and these mice phenocopy RubinsteinTaybi Syndrome (RTS) in humans (we refer to these mice here as RTS mice). Two important differences between our CBP $\Delta 1$ transgenic mice and the RTS mice are that CBP $\Delta 1$ transgenic mice express the truncated CBP mutant in the presence of two wild-type CBP alleles, and that expression is spatially and temporally restricted in CBP $\triangle 1$ transgenic mice to post-natal neurons in specific regions of the brain. As a result, the CBP $\Delta 1$ mutant is less deleterious in our transgenic mice, and we were able to study the role of CBP in memory storage independent of the developmental abnormalities observed in RTS mice.

RTS mice exhibit impaired long-term memory in a stepthrough-avoidance test and cued fear conditioning, with no observable deficits in contextual fear conditioning or the Morris water maze (Oike et al. 1999). RTS mice have also been found to have long-term memory deficits for object recognition (Bourtchouladze et al. 2003). The discrepancy between our results and those of Oike et al. (1999) may be due to the aforementioned differences in the expression of the truncated CBP protein be- 
A

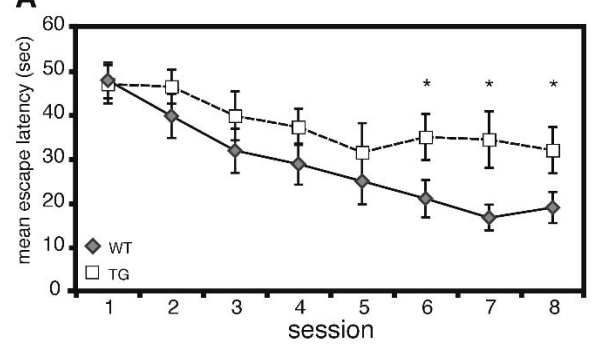

B

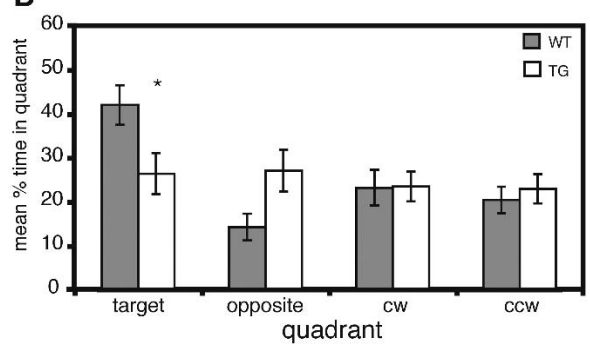

C

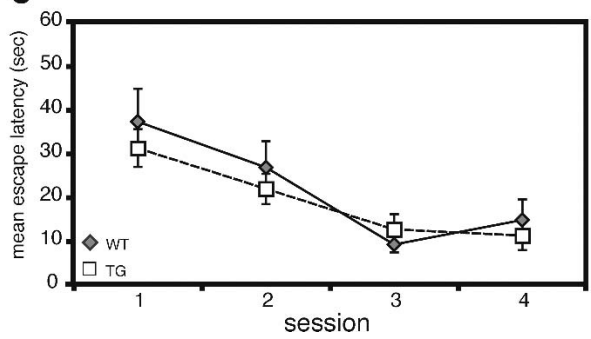

Figure 5. $\quad \mathrm{CBP} \triangle 1$ trangenic mice exhibit impaired spatial learning. $(A)$ Mean escape latency during acquisition of the hidden-platform version of the Morris water maze. CBP $\Delta 1$ transgenic mice $(n=9)$ have a significant overall impairment in acquisition as compared to wild-type littermates $(n=12)$. (B) Mean percent time spent in each quadrant during the posttraining probe trial on day ten. CBP $\Delta 1$ transgenic mice $(n=9)$ spent significantly less time in the target quadrant, where the platform was located during training, than did wild-type littermates $(n=12)$. (C) Mean escape latency during acquisition of the visible-platform version of the Morris water maze. A different group of mice were tested in the visibleplatform experiment than those tested in the hidden-platform experiment. There was no difference observed between CBP $\Delta 1$ transgenic mice $(n=8)$ and wild-type littermates $(n=5)$ in the visible platform version of the Morris water maze. ${ }^{*}$ indicates $p<0.05$.

tween RTS mice (throughout the organism) and CBP $\Delta 1$ transgenic mice (specific areas of the brain), or to the significant developmental abnormalities seen in RTS mice. Additionally, differences in behavioral training protocols and genetic background can contribute significantly to observed differences (Bucan and Abel 2002).

Interestingly, although we observe transgene expression in the amygdala, CBP $\Delta 1$ transgenic mice do not exhibit cued fear conditioning deficits. One possibility for this observation is that the CaMKII $\alpha$ promoter drives expression of a transgene to a lesser extent in the amygdala than the hippocampus. Indeed, transgenic mice expressing a dominant negative mutation of PKA from the CaMKII $\alpha$ promoter express more highly in the hippocampus than the amygdala (Bourtchouladze et al. 2000) and exhibit impaired long-term memory for contextual fear conditioning, but normal long-term memory for cued fear conditioning as well as conditioned taste aversion, two amygdala-dependent tasks (Abel et al. 1997). Another possibility is that different memory systems have differential molecular requirements. Thus, long-term memory for hippocampus-dependent contextual fear conditioning may be more sensitive to alterations in CBP activity, whereas memory for amygdala-dependent cued fear conditioning may not. In support of this last possibility, we have observed that knock-in mice homozygous for point mutations in the CREB-binding domain (KIX) of CBP exhibit significantly impaired long-term memory for contextual fear conditioning, but normal memory for cued fear conditioning (M. Wood, unpubl.). These results are similar to what we have observed in the CBP $\Delta 1$ transgenic mice, suggesting that CBP function is particularly important for hippocampus-dependent forms of memory.

\section{Role for CBP in hippocampal synaptic plasticity}

CBP $\Delta 1$ transgenic mice showed normal tetraburst L-LTP induced by four $100 \mathrm{~Hz}, 1 \mathrm{sec}$ trains and normal E-LTP induced by a single $1 \mathrm{sec}, 100 \mathrm{~Hz}$ train but showed a significant reduction in L-LTP induced by the same $100 \mathrm{~Hz}$ train paired with the dopamine D1 agonist, chloro-APB. This form of LTP was also impaired in trans-
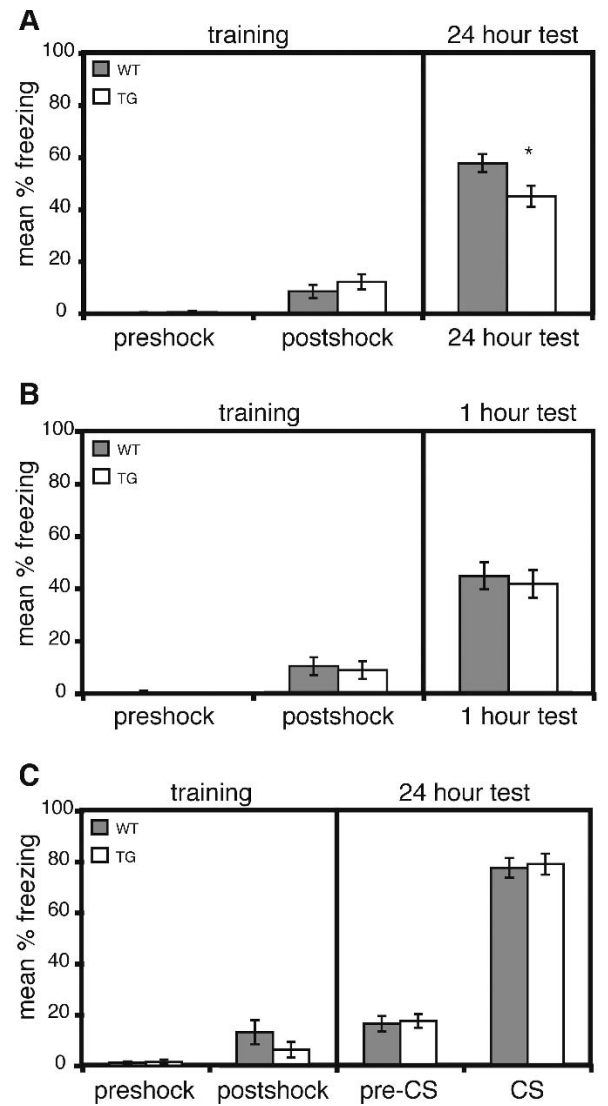

Figure 6. $C B P \Delta 1$ transgenic mice exhibit impaired long-term memory for contextual fear conditioning but normal cued fear conditioning. $(A)$ Training and $24 \mathrm{~h}$ long-term memory test during contextual fear conditioning. There was no difference in freezing behavior between CBP 1 transgenic mice $(n=18)$ and wild-type littermates $(n=20)$ during the first $2.5 \mathrm{~min}$ before the shock is presented (preshock) or the $0.5 \mathrm{~min}$ after the shock (post-shock). However, CBP 1 transgenic mice exhibited a significant decrease in freezing in a $24 \mathrm{~h}$ retention test, performed in the same conditioned context, as compared to wild-type littermates. (B) Training and $1 \mathrm{~h}$ short-term memory test during contextual fear conditioning. CBP $\Delta 1$ transgenic mice $(n=11)$ and wild-type littermates $(n=11)$ showed no differences in freezing in a $1 \mathrm{~h}$ retention test, performed in the same conditioned context. (C) Training and $24 \mathrm{~h}$ long-term memory test during cued fear conditioning. No differences in freezing behavior were observed between CBP $\Delta 1$ transgenic mice $(n=14)$ and wild-type littermates $(n=8)$ during training or the $24 \mathrm{~h}$ retention test. The $24 \mathrm{~h}$ test was performed in a novel context for cued fear conditioning. ${ }^{*}$ indicates $p<0.05$.

\section{Learning \& Memory}


genic mice expressing KCREB, a dominant negative form of CREB (Pittenger et al. 2002). Like our CBP $\Delta 1$ transgenic mice, transgenic mice expressing KCREB showed normal tetraburst L-LTP and normal E-LTP in response to a single train of stimuli. It has become increasingly clear that there are multiple forms of longlasting hippocampal synaptic plasticity, including LTP induced by the pairing of one train with D1 activation (Pittenger et al. 2002), theta-burst stimulation (Woo et al. 2000) and massed or spaced delivery of three or four $100 \mathrm{~Hz}$ tetani (Scharf et al. 2002). These forms of LTP have been shown to differ in their molecular mechanisms. For example, transgenic mice expressing KCREB, show normal L-LTP resulting from theta burst or tetraburst protocols (Pittenger et al. 2002). Further, other studies using different genetic manipulations of CREB in mice have also not found impairments in LTP induced by induction protocols using multiple tetani (Gass et al. 1998; Balschun et al. 2003). The similar phenotypes of reduced LTP induced by pairing of synaptic stimulation with chloro-APB in KCREB and CBP 1 transgenic mice suggests that CBP may be functioning as a transcriptional coactivator for a CREB family member in the Schaffer collateral pathway of the hippocampus to mediate the transcription of genes required for this form of synaptic plasticity. It also raises the intriguing question of what transcriptional mechanisms mediate LTP in response to multiple tetanic trains.

While this manuscript was in preparation, two papers appeared showing that conditional transgenic mice expressing histone acetyltransferase (HAT)-deficient CBP exhibit impaired memory in the Morris water maze and object recognition tasks (Korzus et al. 2004) and that mice heterozygous for a null mutation of CBP exhibit impaired memory for object recognition and contextual fear conditioning (Alarcon et al. 2004). Korzus et al. (2004) were able to ameliorate the object recognition memory deficit by intraperitioneal administration of the histone deacetylase (HDAC) inhibitor trichostatin A (TSA). Alarcon et al. (2004) were able to ameliorate the contextual fear conditioning memory deficit by intracerebroventricular injection of suberoylanilide hydroxamic acid (SAHA). These HDAC inhibitors induce a state of increased histone acetylation that presumably compensates for the lack of CBP histone acetyltransferase activity in the CBP mutant mice. Levenson et al. (2004) demonstrated that HDAC inhibitors enhance induction of LTP at Schaffer-collateral synapses in area CA1 and enhance long-term memory formation for contextual fear conditioning. Additionally, in RTS mice, inhibitors of phosphodiesterase 4 enhance CREB-dependent gene expression and ameliorate memory deficits for object recognition in a dose dependent manner (Bourtchouladze et al. 2003). Interestingly, these authors observed a shift in the dose response curve in the RTS mice as compared to wild-type mice, suggesting that an increased upstream enhancement of the cAMP signaling cascade is necessary to compensate for the downstream disruptions in this pathway caused by the inhibitory truncated CBP mutant expressed in RTS mice. These results agree with our own in pointing to a role for CBP and its histone acetylation activity in memory storage. However, mice heterozygous for a null mutation of CBP exhibit impaired L-LTP induced by four $100 \mathrm{~Hz}$ trains stimulation (Alarcon et al. 2004), a form of LTP that we found to be normal in our CBP $\Delta 1$ transgenic mice. Results from mice heterozygous for a null mutation of CBP are difficult to interpret due to the developmental abnormalities and embryonic lethality present in these mice (Tanaka et al. 1997; Kung et al. 2000). With our transgenic approach, we are able to attribute LTP deficits in CBP $\Delta 1$ transgenic mice to the specific expression of CBP $\Delta 1$ in hippocampal neurons.

Our results demonstrate a role for CBP in hippocampal synaptic plasticity and hippocampus-dependent long-term memory formation. The involvement of CBP, a transcriptional coactivator with histone acetyltransferase activity, in memory storage further defines the complex nature of transcriptional activation required for memory. CBP is recruited to activated transcription factors and then CBP itself is activated to initiate full transcriptional activation. Thus, CBP may provide a mechanism by which multiple signaling cascades are integrated to coordinately regulate gene expression. The future identification of genes regulated by CBP and histone acetylation will be critical to our understanding of the cellular processes activated by CBP during memory storage.

\section{Materials and Methods}

\section{Generation of $\mathrm{CBP} \Delta 1$ transgenic mice}

The full-length wild-type cDNA (pRc/RSV-mCBP.HA.RK; Chrivia et al. 1993) for mouse CBP was kindly provided by Dr. Marc Montminy (The Salk Institute for Biological Studies). Amino acids 1-1084 (CBP 1 ) were cloned into pBluescript II KS (+/-) using BamH1 and Xba1 sites. The truncated CBP cDNA was then FLAG-epitope tagged by Muta-Gene Phagemid In Vitro Mutagenesis (BioRad). FLAG-CBP 1 was cloned into the EcoRV site of MM400, a vector containing the untranslated leader with a hybrid intron (Choi et al. 1991) and SV40 polyA sequences. Then, FLAG-CBP $\Delta 1$ with an untranslated leader and SV40 sequences were cloned into the Not1 site of MM403, which contains the $8.5 \mathrm{~kb}$ mouse CaMKII $\alpha$ promoter (Mayford et al. 1996). All cloning junctions were verified by DNA sequencing.

The FLAG-CBP $\Delta 1$ transgene construct was excised from MM403 using BssHII sites and purified by $\mathrm{CsCl}$ gradient centrifugation. The $13 \mathrm{~kb}$ transgene was isolated by agarose gel electrophoresis, electroeluted, and purified using Elutip (Schleicher and Schuell). Transgenic mice were generated by injecting purified CaMKII $\alpha$-FLAG-CBP $\Delta 1$ transgene into pronuclei of B6-SJL/F1 zygotes (Transgenic and Chimeric Mouse Facility at the University of Pennsylvania). Founders were backcrossed to C57BL/6J mice. Mice were maintained and bred under standard conditions, consistent with National Institute of Health guidelines and approved by the Institutional Animal Care and Use Committee. Mice were maintained on a 12-h light/12-h dark cycle with behavioral testing occurring during the light phase. For experiments, subjects were N2-N4s and 8-12 wk old at the time of testing and had free access to food and water. Littermate mice were used for controls in all experiments. For genotyping, tail DNA was prepared and analyzed by Southern blotting using a transgene-specific probe as previously described (Abel et al. 1997).

\section{In situ hybridization and Nissl staining}

Mouse brains were dissected and flash frozen in 2-methylbutane. Sagittal cryostat sections $(20 \mu \mathrm{m})$ were fixed and hybridized as previously described (Abel et al. 1997). An $\left[\alpha-{ }^{35} \mathrm{~S}\right]$-dATP-labeled, transgene-specific oligonucleotide (5'-GCTTGTCATCATCGTC CTTGTAGTCCATCCCATCCGCAGG-3') was used that hybridizes to the FLAG-epitope and the beginning of the CBP CDNA. Slides were exposed to Kodak Biomax autoradiographic film. For Nissl staining, brains were dissected and flash frozen in liquid nitrogen. Cryostat sections $(20 \mu \mathrm{m})$ were fixed in $4 \%$ paraformaldehyde in PBS.

\section{Northern blot analysis}

Hippocampus, cortex, and cerebellum were dissected and placed in RNAlater (Ambion). Total RNA was then isolated from tissue homogenized in TRIzol reagent (Gibco). Eight micrograms of total RNA for each sample was separated on an RNA borate/ formaldehyde gel and then transferred onto Hybond-XL membrane (Amersham Biosciences). The membrane was then probed with a ${ }^{32}$ P-radiolabeled CBP amino-terminal cDNA fragment, washed and then exposed to XAR-5 film (Kodak). The membrane was then stripped using $0.1 \times$ SSC and $0.1 \%$ SDS at $95^{\circ} \mathrm{C}$ and re-probed with a ${ }^{32} \mathrm{P}$-radiolabeled $\beta$-actin cDNA fragment to normalize loading and transfer. 


\section{Tissue culture}

HEK 293 cells (ATCC) were maintained in Minimum Essential Media with Earle's Salts (Gibco) supplemented with 10\% horse serum (ATCC) and 1\% penicillin/streptomycin (LTI) and grown at $37^{\circ} \mathrm{C}, 5 \% \mathrm{CO}_{2}$. Before transfection, cells at $60 \%-70 \%$ confluence were incubated in serum free media with $1 \%$ penicillin/ streptomycin for $3 \mathrm{~h}$. Cells were transfected with a total of $375 \mathrm{ng}$ plasmid DNA using FuGene 6 Transfection Reagent (Roche) according to manufacturer's protocol. The following plasmids were used: pßgal-Crontrol (BD Biosciences), CRE-Luciferase (Ohda et al. 2003), and CBP $\Delta 1-M M 400$. p $\beta$ gal-Control contains the SV40 early promoter and enhancer sequences inserted upstream and downstream, respectively, of the lacZ gene and was used to normalize the transfection efficiency. CRE-luciferase expresses firefly luciferase under the control of cAMP-responsive element (CRE) and functioned as a reporter. CBP $\Delta 1$-MM400 expresses CBP 1 (residues 1-1084) from the CMV promoter. MM400 was added to keep the amount of DNA in each transfection equal. One day after transfection, the cells were treated with $10 \mu \mathrm{M}$ of forskolin (Sigma) and $10 \mu \mathrm{M}$ of IBMX (Sigma) and incubated for $6 \mathrm{~h}$. At the end of incubation, cells were harvested and assayed for luciferase activity with the Luciferase Assay System with Reporter Lysis Buffer (Promega) and $\beta$-Galactosidase activity with $\beta$-Gal Reporter Gene Assay (Roche).

\section{Electrophysiological analysis}

Acute, transverse hippocampal slices (400 $\mu \mathrm{m}$ thick) were prepared from 8- to 12-wk old transgenics and wild-type controls and maintained in an interface chamber (Abel et al. 1997). Sections were continuously perfused with oxygenated artificial cerebrospinal fluid (ACSF) at $31^{\circ} \mathrm{C}, \mathrm{pH} 7.4$ and allowed to recover for at least $2 \mathrm{~h}$ after dissection before starting electrophysiological experiments. Action potentials were elicited once per minute in CA3 axons with a bipolar stimulating electrode (A-M systems, Inc.; 0.002 inch diameter nichrome wire) placed in the stratum radiatum, with the stimulus intensity set to produce $40 \%$ of the maximum response. The resulting field potentials (fEPSPs) were recorded using a glass microelectrode (A-M systems, Inc.; $1.5 \mathrm{~mm}$ $\times 0.85 \mathrm{~mm}$ ) filled with ACSF with resistance between 1 and 2 $\mathrm{M} \Omega$, placed in the stratum radiatum of CA1. Data were acquired using Clampex 7 (Axon Instruments, Inc.) and exported to Igor 4.05A (Wavemetrics, Inc.), where both peak amplitude and initial slope of fEPSPs were calculated. Slices with peak amplitudes less than $2.5 \mathrm{mV}$ were not utilized. Paired-pulse facilitation was assessed at interstimulus intervals ranging from 25 to $300 \mathrm{msec}$. For slices in which the presynaptic fiber volley was distinguishable, input-output relations were characterized by plotting the initial slope of the fEPSP against the amplitude of the presynaptic fiber volley. For E-LTP experiments, baseline responses were monitored for at least 15 min before applying one train of stimuli at $100 \mathrm{~Hz}$ for $1 \mathrm{sec}$. L-LTP was induced using two stimulus protocols: a tetraburst protocol consisting of four $100 \mathrm{~Hz}, 1 \mathrm{sec}$ trains of stimuli administered $5 \mathrm{~min}$ apart, or a single $100 \mathrm{~Hz}, 1 \mathrm{sec}$ train delivered after $25 \mathrm{~min}$ in the presence of $10 \mu \mathrm{M}$ chloro-APB (Sigma), a D1 agonist, delivered in $0.05 \%$ EtOH. For both types of L-LTP experiments, baseline responses were monitored for at least $15 \mathrm{~min}$, and recordings were continued for at least $2 \mathrm{~h}$ following LTP induction. Initial fEPSP slopes were normalized against the average of the last 20 responses before LTP induction and expressed as percent. Post-tetanic potentiation was assessed relative to baseline responses, $1 \mathrm{~min}$ after the $100 \mathrm{~Hz}$ train.

\section{Water maze}

The hidden and visible platform water maze experiments were performed in a circular pool using the methods previously described (Lattal and Abel 2001a), except that two trials per day (4-6 min intertrial interval) were given during the eight training days and mice were handled for 1 min every day for three days before training began. Briefly, on the first day, mice were trained to sit on a submerged platform in a bucket for two $30 \mathrm{sec}$ trials. Then, mice were trained for four days, a probe trial was given on the fifth day, then four more days of training occurred (to the same platform location) followed by a second probe trial on the tenth day. The platform was removed during probe trials on the fifth and tenth days, which lasted for $1 \mathrm{~min}$ and were followed by a $20 \mathrm{sec}$ platform sit. The nonspatial version of the water maze was performed by attaching a visible cue to the platform, which was placed in different locations during each of the two trials per day, for four consecutive days. Naive animals were used for the visible platform task. The path of the mouse was recorded using a video tracking system (HVS Image, Water2020 version 1/2001).

\section{Fear conditioning}

Fear conditioning experiments were performed in chambers using the methods previously described (Lattal and Abel 2001b). Mice were handled for three consecutive days for $1 \mathrm{~min}$ each day. For contextual fear conditioning, mice were placed into the conditioning chamber and received a $2 \mathrm{sec} 1.5 \mathrm{~mA}$ scrambled footshock $2.5 \mathrm{~min}$ after placement into the chamber. Mice were removed from the chamber after 3 min. During testing, mice received one 5 min exposure to the same conditioned context in the absence of shock 1 or $24 \mathrm{~h}$ after conditioning. Different sets of mice were used for the $1 \mathrm{~h}$ and $24 \mathrm{~h}$ retention tests. For cued fear conditioning, mice were placed into the chamber and the cue (white noise) was activated from 2-2.5 min after placement into the chamber with a $2 \mathrm{sec} 1.5 \mathrm{~mA}$ footshock $2.5 \mathrm{~min}$ after placement into the chamber. Mice were removed from the chamber after a total of $3 \mathrm{~min}$. On testing day, mice in the cued group received one $5 \mathrm{~min}$ exposure to a novel context (another conditioning chamber with smooth flat floor, altered dimensions, and a novel odorant) for 0-2 min (pre-CS) followed by exposure to the cue from 2-5 min (CS), $24 \mathrm{~h}$ after conditioning. Conditioning was assayed by measuring freezing behavior, the complete absence of movement (Fanselow 1980). Freezing was scored during conditioning as well as testing. The behavior of each mouse was sampled at $5 \mathrm{sec}$ intervals and the percentage of those intervals in which the mouse froze was calculated. Different sets of mice were used for contextual and cued conditioning experiments.

\section{Data analysis}

Analyses of variance (ANOVAs) were performed in all experiments using SigmaStat (version 2.03) and Systat (version 7.0.1). Repeated measures ANOVA were used where appropriate. Simple planned comparisons were made using Student's $t$-test. There were no overall significant differences between males and females for either the wild type or transgenic groups, therefore results were collapsed for final data analysis. Experimenters were blind to genotype and genotypes were confirmed by Southern blot analysis or PCR following behavioral and electrophysiological tests.

\section{Acknowledgments}

We thank Dr. Jean Richa at the Transgenic and Chimeric Mouse Facility at the University of Pennsylvania for generating CBP $\Delta 1$ transgenic animals, Dr. Marc Montminy for the mouse CBP cDNA, and Dr. Michele P. Kelly for help with statistical analysis. We thank Dr. Tom Gould, Dr. Matt Lattal, and Conor McDonough for comments on the manuscript. This research was supported by a SFN MNFP post-doctoral fellowship (to M.A.W.), post-doctoral Training Program fellowship in Neuropsychopharmacology (to M.K.), and by grants from the Merck Foundation, the National Institutes of Health, the Packard Foundation, the University of Pennsylvania Research Foundation, and the Whitehall Foundation (to T.A.).

\section{References}

Abel, T., Nguyen, P.V., Barad, M., Deuel, T.A., Kandel, E.R., and Bourtchouladze, R. 1997. Genetic demonstration of a role for PKA in the late phase of LTP and in hippocampus-based long-term memory. Cell 88: 615-626.

Alarcon, J.M., Malleret, G., Touzani, K., Vronskaya, S., Ishii, S., Kandel, E.R., and Barco, A. 2004. Chromatin acetylation, memory, and LTP are impaired in $\mathrm{CBP}(+/-)$ mice: A model for the cognitive deficit in

\section{Learning \& Memory}


Rubinstein-Taybi Syndrome and its amelioration. Neuron 42: 947959.

Balschun, D., Wolfer, D.P., Gass, P., Mantamadiotis, T., Welzl, H. Schutz, G., Frey, J.U., and Lipp, H.P. 2003. Does cAMP response element-binding protein have a pivotal role in hippocampal synaptic plasticity and hippocampus-dependent memory? J. Neurosci. 23: 6304-6314.

Bliss, T.V. and Richter-Levin, G. 1993. Spatial learning and the saturation of long-term potentiation. Hippocampus 3: 123125.

Bolstad, B.M., Irizarry, R.A., Astrand, M., and Speed, T.P. 2003. A comparison of normalization methods for high density oligonucleotide array data based on variance and bias. Bioinformatics 19: $185-193$

Bourtchouladze, R., Abel, T., Bailey, C.H., and Kandel, E.R. 2000. A common requirement for PKA signaling in hippocampus suggests a similarity in the molecular storage mechanism between trace and contextual conditioning. Society for Neuroscience Abstract 26: 1509.

Bourtchouladze, R., Lidge, R., Catapano, R., Stanley, J., Gossweiler, S., Romashko, D., Scott, R., and Tully, T. 2003. A mouse model of Rubinstein-Taybi syndrome: Defective long-term memory is ameliorated by inhibitors of phosphodiesterase 4. Proc. Natl. Acad. Sci. 100: 10518-10522.

Bucan, M. and Abel, T. 2002. The mouse: Genetics meets behaviour. Nat. Rev. Genet. 3: 114-123.

Cantani, A. and Gagliesi, D. 1998. Rubinstein-Taybi syndrome. Review of 732 cases and analysis of the typical traits. Eur. Rev. Med. Pharmacol. Sci. 2: 81-87.

Choi, T., Huang, M., Gorman, C., and Jaenisch, R. 1991. A generic intron increases gene expression in transgenic mice. Mol. Cell. Biol. 11: $3070-3074$.

Chrivia, J.C., Kwok, R.P., Lamb, N., Hagiwara, M., Montminy, M.R., and Goodman, R.H. 1993. Phosphorylated CREB binds specifically to the nuclear protein CBP. Nature 365: 855-859.

Coupry, I., Monnet, L., Attia, A.A., Taine, L., Lacombe, D., and Arveiler, B. 2004. Analysis of CBP (CREBBP) gene deletions in RubinsteinTaybi syndrome patients using real-time quantitative PCR. Hum. Mutat. 23: 278-284.

D'Hooge, R. and De Deyn, P.P. 2001. Applications of the Morris water maze in the study of learning and memory. Brain Res. Rev. 36: 60-90.

Fanselow, M.S. 1980. Conditional and unconditional components of post-shock freezing. Pavlovian J. of Biol. Sci. 95: 177-182.

Gass, P., Wolfer, D.P., Balschun, D., Rudolph, D., Frey, U., Lipp, H., and Schutz, G. 1998. Deficits in memory tasks of mice with CREB mutations depend on gene dosage. Learn. Mem. 5: 274-288.

Goodman, R.H. and Smolik, S. 2000. CBP/p300 in cell growth, transformation, and development. Genes \& Dev. 14: 1553-1577.

Hennekam, R.C., Baselier, A.C., Beyaert, E., Bos, A., Blok, J.B., Jansma, H.B., Thorbecke-Nilsen, V.V., and Veerman, H. 1992. Psychological and speech studies in Rubinstein-Taybi syndrome. Am. J. Ment. Retard. 96: 645-660.

Kamei, Y., Xu, L., Heinzel, T., Torchia, J., Kurokawa, R., Gloss, B., Lin, S.C., Heyman, R.A., Rose, D.W., Glass, C.K., et al. 1996. A CBP integrator complex mediates transcriptional activation and AP-1 inhibition by nuclear receptors. Cell 85: 403-414.

Kaplan, M.P. and Abel, T. 2003. Genetic approaches to the study of synaptic plasticity and memory storage. CNS Spectr. 8: 597610.

Kogan, J.H., Frankland, P.W., Blendy, J.A., Coblentz, J., Marowitz, Z., Schütz, G., and Silva, A. 1997. Spaced training induces normal long-term memory in CREB mutant mice. Curr. Biol. 7: 1-11.

Kojima, N., Wang, J., Mansuy, I.M., Grant, S.G., Mayford, M., and Kandel, E.R. 1997. Rescuing impairment of long-term potentiation in fyn-deficient mice by introducing Fyn transgene. Proc. Natl. Acad. Sci. 94: $4761-4765$.

Korzus, E., Rosenfeld, M.G., and Mayford, M. 2004. CBP histone acetyltransferase activity is a critical component of memory consolidation. Neuron 42: 961-972.

Kung, A.L., Rebel, V.I., Bronson, R.T., Ch'ng, L.E., Sieff, C.A., Livingston, D.M., and Yao, T.P. 2000. Gene dose-dependent control of hematopoiesis and hematologic tumor suppression by CBP. Genes \& Dev. 14: 272-277.
Lattal, K.M. and Abel, T. 2001a. Different requirements for protein synthesis in acquisition and extinction of spatial preferences and context-evoked fear. J. Neurosci. 21: 5773-5780.

- 2001b. An immediate-shock freezing deficit with discrete cues: A possible role for unconditioned stimulus processing mechanisms. J. Exp. Psychol. Anim. Behav. Process. 27: 394-406.

LeDoux, J.E. 2000. Emotion circuits in the brain. Annu. Rev. Neurosci. 23: $155-184$.

Levenson, J.M., O'Riordan, K.J., Brown, K.D., Trinh, M.A., Molfese, D.L., and Sweatt, J.D. 2004. Regulation of histone acetylation during memory formation in the hippocampus. J. Biol. Chem. 39: 40545-40559.

Lipp, H.P. and Wolfer, D.P. 1998. Genetically modified mice and cognition. Curr. Opin. Neurobiol. 8: 272-280.

Lonze, B. and Ginty, D. 2002. Function and regulation of CREB family transcription factors in the nervous system. Neuron 35: 605-623.

Maren, S. 2001. Neurobiology of Pavlovian fear conditioning. Annu. Rev. Neurosci. 24: 897-931.

Martin, S.J. and Morris, R.G. 2002. New life in an old idea: The synaptic plasticity and memory hypothesis revisited. Hippocampus 12: 609636.

Mayford, M., Bach, M.E., Huang, Y.-Y., Wang, L., Hawkins, R.D., and Kandel, E.R. 1996. Control of memory formation through regulated expression of a CaMKII transgene. Science 274: 1678-1683.

Ohda, Y., Wang, L., Ahn, R.S., Park, J.Y., Seong, J.Y., and Kwon, H.B. 2003. Differential G protein coupling preference of mammalian and nonmammalian gonadotropin-releasing hormone receptors. Mol. Cell. Endocrinol. 205: 89-98.

Oike, Y., Hata, A., Mamiya, T., Kaname, T., Noda, Y., Suzuki, M., Yasue, H., Nabeshima, T., Araki, K., and Yamamura, K. 1999. Truncated CBP protein leads to classical Rubinstein-Taybi syndrome phenotypes in mice: implications for a dominant-negative mechanism. Hum. Mol. Genet. 8: 387-396.

Petrij, F., Giles, R.H., Dauwerse, H.G., Saris, J.J., Hennekam, R.C.M., Masuno, M., Tommerup, N., van Ommen, G.-J.B., Goodman, R.H., Peters, D.J.M., et al. 1995. Rubinstein-Taybi syndrome caused by mutations in the transcriptional co-activator CBP. Nature 376: 348-351.

Pittenger, C., Huang, Y.Y., Paletzki, R.F., Bourtchouladze, R., Scanlin, H., Vronskaya, S., and Kandel, E.R. 2002. Reversible inhibition of $\mathrm{CREB} / \mathrm{ATF}$ transcription factors in region CA1 of the dorsal hippocampus disrupts hippocampus-dependent spatial memory. Neuron 34: 447-462.

Rubinstein, J.H. and Taybi, H. 1963. Broad thumbs and toes and facial abnormalities. A possible mental retardation syndrome. Am. J. Dis. Child 105: 588-608.

Scharf, M.T., Woo, N.H., Lattal, K.M., Young, J.Z., Nguyen, P.V., and Abel, T. 2002. Protein synthesis is required for the enhancement of long-term potentiation and long-term memory by spaced training. J. Neurophysiol. 87: 2770-2777.

Schenk, F. and Morris, R.G. 1985. Dissociation between components of spatial memory in rats after recovery from the effects of retrohippocampal lesions. Exp. Brain Res. 58: 11-28.

Tanaka, Y., Naruse, I., Maekawa, T., Masuya, H., Shiroishi, T., and Ishii, S. 1997. Abnormal skeletal patterning in embryos lacking a single Cbp allele: A partial similarity with Rubinstein-Taybi syndrome. Proc. Natl. Acad. Sci. 94: 10215-10220.

Tusher, V.G., Tibshirani, R., and Chu, G. 2001. Significance analysis of microarrays applied to the ionizing radiation response. Proc. Natl. Acad. Sci. 98: 5116-5121.

Vo, N., and Goodman, R.H. 2001. CREB-binding protein and p300 in transcriptional regulation. J. Biol. Chem. 276: 13505-13508.

Woo, N.H., Duffy, S.N., Abel, T., and Nguyen, P.V. 2000. Genetic and pharmacological demonstration of differential recruitment of cAMP-dependent protein kinases by synaptic activity. J. Neurophysiol. 84: $2739-2745$.

Wood, M.A., McMahon, S.B., and Cole, M.D. 2000. An ATPase/helicase complex is an essential cofactor for oncogenic transformation by c-Myc. Mol. Cell 5: 321-330.

Zucker, R.S. 1989. Short-term synaptic plasticity. Annu. Rev. Neurosci. 12: $13-31$.

Received September 24, 2004; accepted in revised form January 4, 2005. 


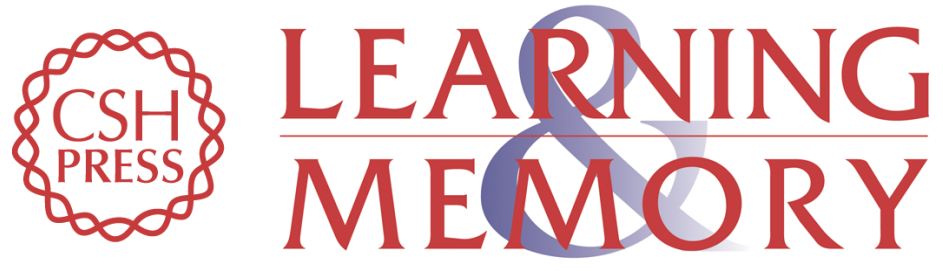

\section{Transgenic mice expressing a truncated form of CREB-binding protein (CBP) exhibit deficits in hippocampal synaptic plasticity and memory storage}

Marcelo A. Wood, Michael P. Kaplan, Alice Park, et al.

Learn. Mem. 2005, 12:

Access the most recent version at doi:10.1101//m.86605

References This article cites 44 articles, 12 of which can be accessed free at: http://learnmem.cshlp.org/content/12/2/111.full.html\#ref-list-1

License

Email Alerting

Receive free email alerts when new articles cite this article - sign up in the box at the Service top right corner of the article or click here. 